\title{
Bariatric surgery and its impact on cardiovascular disease and mortality: a systematic review and meta-analysis
}

\author{
Chun Shing Kwok ${ }^{1}$, Ash Pradhan ${ }^{2}$, Muhammad A Khan ${ }^{3}$, Simon G Anderson ${ }^{4}$, \\ Bernard D Keavney, , Phyo Kyaw Myint ${ }^{6}$, Mamas A Mamas ${ }^{7}$, Yoon K Loke ${ }^{8}$ \\ ${ }^{1}$ Cardiovascular Institute, University of Manchester, Manchester, UK \\ "This author takes responsibility for all aspects of the reliability and freedom from \\ bias of the data presented and their discussed interpretation"
}

${ }^{2}$ Royal Preston Hospital, Fulwood, Preston, UK.

"This author takes responsibility for all aspects of the reliability and freedom from bias of the data presented and their discussed interpretation"

${ }^{3}$ Cardiovascular Institute, University of Manchester, Manchester, UK

"This author takes responsibility for all aspects of the reliability and freedom from bias of the data presented and their discussed interpretation"

${ }^{4}$ Cardiovascular Institute, University of Manchester, Manchester, UK

"This author takes responsibility for all aspects of the reliability and freedom from bias of the data presented and their discussed interpretation"

${ }^{5}$ Cardiovascular Institute, University of Manchester, Manchester, UK

"This author takes responsibility for all aspects of the reliability and freedom from bias of the data presented and their discussed interpretation"

${ }^{6}$ School of Medicine \& Dentistry, University of Aberdeen, Foresterhill, Aberdeen, UK "This author takes responsibility for all aspects of the reliability and freedom from bias of the data presented and their discussed interpretation"

${ }^{7}$ Cardiovascular Institute, University of Manchester, Manchester, UK

"This author takes responsibility for all aspects of the reliability and freedom from bias of the data presented and their discussed interpretation"

${ }^{8}$ Norwich Medical School, University of East Anglia, Norwich, UK

"This author takes responsibility for all aspects of the reliability and freedom from bias of the data presented and their discussed interpretation"

\section{Correspondence to:}

Chun Shing Kwok

Institute of Cardiovascular Sciences, University of Manchester, Manchester Royal Infirmary, Manchester, UK, M13 9WL

Tel: +44 (0) 1612768666

Fax: +44 (0) 1612767956

Mail to: shingkwok@doctors.org.uk

Acknowledgements: None. 
Conflict of interest disclosures: The authors have no conflicts of interest to declare.

Keywords: obesity; bariatric surgery; cardiovascular disease; myocardial infarction; stroke; mortality 


\section{Structured Abstract}

Background: Bariatric surgery has been shown to improve cardiovascular risk factors but long term benefit for survival and cardiovascular events are still uncertain.

Methods: We searched MEDLINE and EMBASE for parallel group studies that evaluated the clinical outcomes associated with bariatric surgery as compared to nonsurgical treatment. Relevant studies were pooled using randomized effects metaanalysis for risk of myocardial infarction, stroke, cardiovascular events and mortality. Results: 14 studies met the inclusion criteria, which included 29,208 patients who underwent bariatric surgery and 166,200 nonsurgical controls (mean age 48 years, $30 \%$ male, follow up period ranged from 2 years to 14.7 years). Four studies were considered at moderate-high risk of bias, while the ten studies were at moderate or lower risk of bias. Compared to nonsurgical controls there was more than $50 \%$ reduction in mortality among patients who had bariatric surgery (OR 0.48 95\% CI $0.35-0.64, \mathrm{I}^{2}=86 \%, 14$ studies). In pooled analysis of four studies with adjusted data, bariatric surgery was associated with a significantly reduced risk of composite cardiovascular adverse events (OR 0.54 95\% CI 0.41-0.70, $\mathrm{I}^{2}=58 \%$ ). Bariatric surgery was also associated with significant reduction in specific endpoints of myocardial infarction (OR 0.46 95\% CI 0.30-0.69, $\mathrm{I}^{2}=79 \%$, 4 studies) and stroke (OR 0.49 95\% CI $0.32-0.75, \mathrm{I}^{2}=59 \%, 4$ studies).

Conclusions: Data from observational studies indicates that patients undergoing bariatric surgery have a reduced risk of myocardial infarction, stroke, cardiovascular events and mortality_compared to non-surgical controls. Future randomised studies should investigate whether these observations are reproduced in a clinical trials setting. 


\section{Introduction}

Obesity is a worldwide problem with significant consequences on individuals and society. The global age-standardized prevalence of obesity has nearly doubled from 6.4\% in 1980 to $12 \%$ in 2008.[1] Obesity is associated with cardiovascular disease, type 2 diabetes, several cancers, diminished average life expectancy,[2] and significant impairments in quality of life.[3] In addition, overweight or obesity in young adulthood and middle age has long-term adverse consequences for health care costs in older age.[4] While people may reduce their weight by dieting, physical activity, behavioral modification or consumption of drugs such as orlistat, many people find it difficult to consistently maintain any reduction in weight.[5] Bariatric surgery is an option that has been shown to be associated with significant weight reduction compared to non-surgical control groups, and potentially confers improvements in disease conditions associated with obesity.[6]

The effect of bariatric surgery on a number of endpoints has been extensively studied in the literature. Pontirroli et al conducted a systematic review and meta-analysis of 8 studies with 44,022 participants and found that compared to controls, surgery was associated with a reduced mortality (OR 0.55 95\% CI 0.49-0.63).[7] Another metaanalysis has shown that bariatric surgery has significant benefits on cardiovascular risk factors including hypertension, diabetes and hyperlipidemia.[8] In addition, there is evidence to suggest that it results in resolution of major comorbidities including metabolic syndrome, non-alcoholic fatty liver disease, nephropathy, left ventricular hypertrophy and obstructive sleep apnea.[9] However, there has yet to be a systematic review which evaluates the impact of bariatric surgery on cardiovascular events. 
In this study, we performed a systematic review and meta-analysis to evaluate the impact of bariatric surgery on long-term incident cardiovascular disease and mortality. 


\section{Methods}

\section{Eligibility criteria}

We selected randomized trials and controlled observational studies (case-control or cohort design) that evaluated the association of bariatric surgery and clinical outcomes. The following criteria were used for inclusion:

1. sample size of $>100$ participants undergoing bariatric surgery.

2. control group consisting of participants with non-surgical management, either in the same healthcare setting or as community-based controls.

3. aimed to evaluate one of the following outcomes: myocardial infarction/ischemic heart disease/coronary heart disease, stroke or mortality.

There was no restriction on whether the study has to be prospective or retrospective nor were there any restriction on the type of bariatric surgery.

\section{Search strategy}

We searched MEDLINE and EMBASE from inception up to August 2013 (NHS Evidence) with no language limitations using the broad free-text and indexing search terms [(bariatric surgery) AND ((acute coronary syndrome) OR (ischemic heart disease) OR (ischaemic heart disease) OR (coronary heart disease) OR (stroke) OR (cerebrovascular accident) OR (mortality) OR (cardiovascular disease))] (Supplementary Data 1). In addition, we signed up with PubMed to receive automated electronic notifications for any new articles containing the 'bariatric surgery'. Bibliographies of included studies and recent review articles were checked for additional relevant studies. 


\section{Study selection and data extraction}

Two reviewers (CSK and AP) evaluated all titles and abstracts for studies that met the inclusion criteria, and excluded any articles that clearly did not meet the selection criteria. The potential inclusions were checked by one author (YKL). Full reports (where available) of potentially relevant studies were retrieved and independently checked for eligibility. Data from the included studies were then extracted by one of three reviewers (CSK or AP or MAK) who collected information on study design, drug exposure, study location, characteristics of participants onto a pre-formatted spreadsheet. The data table was then checked (in an unblinded manner) by at least one other reviewer (MAM or YKL). For the outcomes data, CSK and YKL independently extracted odds ratios (unadjusted or adjusted) where available; otherwise raw numbers were recorded to enable calculation of unadjusted odds ratios. If a study had two or more groups of control participants, we pooled the data together to create a single comparator arm.

Any uncertainties or discrepancies were resolved through re-checking against the source papers, and through discussion with another reviewer. Also, we contacted authors if there were any areas that required clarification.

\section{Assessment of risk of bias}

We developed our risk of bias assessment considering the recommendations of the Cochrane Adverse Effects Methods Group. Here, our risk of bias assessment included the selection of treatment group (bariatric surgery) and control group (no bariatric surgery), the ascertainment of clinical outcome, the extent of loss to follow up, the use 
of propensity matching or adjustment for confounders and the generalizability of the study.[10] Generalizability was assessed by considering whether the treatment group and control group were representative of the obese patients treated with surgery and obese patients living in the community, respectively. We aimed to generate funnel plots to assess the possibility of publication bias, provided that there were $>10$ studies available in the meta-analysis, with no evidence of substantial statistical heterogeneity.[11]

\section{Data analysis}

We used RevMan 5.2. (Nordic Cochrane Centre) to conduct random effects metaanalysis using inverse variance method for pooled odds ratios (OR). We assumed similarity between the risk ratio and odds ratio because the incidence of adverse outcomes was low.[12] We evaluated both adjusted and unadjusted data from primary studies, although we preferentially used adjusted data where available.

Statistical heterogeneity was assessed using $I^{2}$ statistic,[13] with $I^{2}$ values of 30-60\% representing a moderate level of heterogeneity. Pre-specified sensitivity analysis was performed by evaluating the effect of using adjusted as opposed to crude estimates, and with exclusion of studies at moderate-high risk of bias. We also aimed to consider non-diabetic and diabetic cohorts separately. 


\section{Results}

Our search yielded 2764 potentially relevant articles and after removal of duplicates there were 2295 titles and abstracts, which were screened. There were 30 potentially relevant articles and the full text of these articles was retrieved and 14 studies met the inclusion criteria after full text review.[14-28] The process of study selection is shown in Figure 1.

The available study designs consisted of three prospective cohorts [15, 20,26,27] and 6 retrospective cohort [16,19,22,23,25], plus 5 cohort studies [17,18,21,24,26] where it was unclear if they were prospective or retrospective. These studies took place between 1984 and 2011 in USA, Canada, Italy, Australia and Sweden. There were a total of 195,408 participants (range 289 to 66,109 participants) with 29,208 patients undergoing bariatric surgery and 166,200 nonsurgical controls. The mean age of participants in these studies was 48 years and $30 \%$ of participants were male. Study characteristic are summarized in Table 1.

The quality assessment of the included studies is shown in Table 2. Some extent of lost to follow up was present in four studies $[15,17,25,28]$, with the greatest loss seen in Sowemimo 2007 (>10\% of cohort with missing data) [28]. Four studies presented unadjusted results for some of the outcomes.[15,18,20,21] Overall, four studies were considered to be of moderate-high risk of bias due to lack of adjustment for confounders or substantial loss to follow-up ,[15,18,20,28] while the others were at moderate or lower risk of bias. 
The types of bariatric surgery and control groups, their follow up and outcome events or risk estimates are shown in Table 3. Three studies did not specifically specify the type of bariatric surgery performed.[16,21,22] Two studies only included obese participants with type 2 diabetes[16,21] and one study used orthopedic and gastrointestinal surgical patients as control groups.[25] The follow up of the included studies ranged from up to 2 years to over 14.7 years. All include studies reported mortality outcome, and four studies evaluated myocardial infarction and stroke events, as well as a cardiovascular composite which typically consisted of mortality, myocardial infarction and stroke.[14,21,25-27]

\section{Mortality outcomes}

The analysis of risk of mortality with and without bariatric surgery is shown in Figure

2. The absolute event rates for each study for relevant outcomes are reported in Supplementary Table 1 . Compared to nonsurgical controls, there was more than $50 \%$ reduction in mortality amongst patients who underwent bariatric surgery (OR 0.48 95\% CI 0.35-0.64, $\mathrm{I}^{2}=86 \%$, crude rate 1,059/29,208 (3.6\%) vs. 18,962/166,200 (11.4\%), 14 studies). The pooled estimate from adjusted data yielded a more conservative and less heterogeneous association, OR 0.60 (95\% CI 0.49 -0.74, $\mathrm{I}^{2}=64 \%$, crude rate $998 / 24,967$ (4.0\%) vs. $12,210 / 146,264$ (8.3\%), 10 studies) than the unadjusted estimates. (Figure 2)

We also looked at subgroup of studies based on risk of bias, presence of diabetes mellitus, or on selection of controls. Exclusion of four studies with moderate-high risk of bias showed that the there was a significant reduction in mortality (adjusted OR $0.6795 \%$ CI $0.59-0.77, I^{2}=25 \%$, crude rate 1,013/26,639 (3.8\%) vs. 13,179/159,523 
(8.3\%)). There were insufficient studies (two studies) to statistically pool to evaluate the risk of mortality and only included patients with diabetes. The study that had adjusted for confounders showed a non-significant trend towards reduction of mortality with bariatric surgery (OR 0.54 95\% CI 0.23-1.28, crude rate 5/1,395 (0.4\%) vs. 484/62,322 (0.8\%) [16] while the other study showed a significant reduction in mortality with surgery (OR 0.20 95\% CI 0.15-0.27, crude rate 41/2,580 (1.6\%) vs. 985/13,371 (7.4\%)).[21] One other study used non-bariatric surgical controls which showed a non-significant trend towards reduction of mortality with bariatric surgery (OR 0.60 95\% CI 0.0.34-1.06, crude rate 82/4,747 (1.7\%) vs. 358/4,393 (8.1\%)).[25]

\section{Cardiovascular endpoints}

Four studies were included in the evaluation of the risk of the composite cardiovascular adverse event endpoint. All four studies presented adjusted risk estimates for the composite endpoint, and we found a significant reduction in risk associated with bariatric surgery (OR $0.5495 \%$ CI $0.41-0.70, \mathrm{I}^{2}=58 \%$, crude rate 407/17,262 (2.4\%) vs. 1,108/27,726 (4.0\%)) (Figure 3).

Bariatric surgery was associated with significant reduction in myocardial infarction and stroke (Figures 4 and 5). Four studies with similar nonsurgical obese controls were pooled and there was a significant associated reduction in myocardial infarction (OR 0.46 95\% CI 0.30-0.69, $\mathrm{I}^{2}=79 \%$, crude rate 226/17,262 (1.3\%) vs. 691/27,726 (2.5\%), 4 studies). The pooled estimate from studies with adjusted data yielded more conservative association of bariatric surgery with myocardial infarction (OR 0.58 95\% CI 0.45-0.74, $\mathrm{I}^{2}=44 \%$, crude rate 218/14,682 (1.5\%) vs. 450/14,355 (3.1\%), 3 studies) 
as compared to unadjusted estimates (OR 0.17 95\% CI 0.08-0.35, crude rate 8/2,580 (0.3\%) vs. 241/13,371 (1.8\%), 1 study). For the stroke endpoint, pooled results of the same four studies yielded a significant associated reduction in stroke (OR 0.49 95\% CI 0.32-0.75, $\mathrm{I}^{2}=59 \%$, crude rate 129/17,262 (0.7\%) vs. 405/27,726 (1.5\%), 4 studies). Again, pooled estimates using adjusted data yielded more conservative estimates of benefit associated with bariatric surgery (OR 0.63 95\% CI 0.49-0.80, $\mathrm{I}^{2}=0 \%$, crude rate $118 / 14,682(0.8 \%)$ vs. 191/14,355 (1.3\%), 3 studies) as compared to unadjusted estimates (OR 0.26 95\% CI 0.14-0.48, crude rate 11/2,580 (0.4\%) vs. 214/13,371 (1.6\%)). 


\section{Discussion}

This is the first meta-analysis demonstrating that bariatric surgery is associated with a reduced risk of myocardial infarction, stroke and composite adverse cardiovascular events. The reduction in risk of these events was approximately $50 \%$ after bariatric surgery compared to non-operated cohorts. In terms of absolute event rates, we found that there were lower fraction of events in the bariatric surgery group compared to non-operated overweight control groups for all outcomes (mortality 3.6\% vs. 11.4\%, cardiovascular events $2.4 \%$ vs. $4.0 \%$, myocardial infarction $1.3 \%$ vs. $2.5 \%$ and stroke $0.8 \%$ vs. $1.5 \%$ ). We found similar reductions for risk of mortality. The magnitude of the effect estimates was greatest in studies with unadjusted estimates but the consideration of only adjusted estimates yielded significant reductions in all adverse events. These finding suggest that patients who are both candidates for bariatric surgery and are at high risk of cardiovascular events should have bariatric surgery.

Our study finding of reduction in CV events with bariatric surgery is supported by the findings of several existing studies which examined the effect of surgery on intermediate risk factors for CVD. A recent meta-analysis by Gloy et al included 11 randomized trials with 796 participants, and found that bariatric surgery was associated with significant reductions in weight, plasma triglyceride levels, plasma LDL cholesterol levels, HbA1c levels and increases in plasma HDL levels and rates of remission of diabetes but no significant difference in plasma cholesterol.[29] Another systematic review evaluated the effect of bariatric surgery on 73 different cardiovascular risk factors in 18 studies with 19543 participants.[8] The key findings of this meta-analysis was that bariatric surgery was associated with reduction of 
weight, hypertension, diabetes, hyperlipidaemia and significant improvements in echocardiographic parameters. Similar findings were found in a recent meta-analysis and meta-regression which found that bariatric surgery has early beneficial impacts on type 2 diabetes, hypertension and hyperlipidaemia.[30] While these systematic reviews consistently show that bariatric surgery is associated with significant improvements in cardioprotective risk factors none of them reported the effect on future cardiovascular event.

The effects of bariatric surgery at physiological and cellular levels has been previously reviewed.[31] It directly reduces the number of adipocytes which leads to decreased levels of leptin and resistin [32,33] and studies suggest that these hormones may have a role in atherogenesis [34, 35]. In addition, surgery impacts the endothelium directly causing decreases in E-selectin, P-selectin and ICAM-1 [36-38] which are believed to be the markers that reflect the level of established cardiovascular risk [39]. The intervention also appears to reduce systemic inflammation and oxidative stress which are important processes in atherosclerosis; reduction in the levels of C-reactive protein, siallic acid, PAI-1, malondialdehyde and von Willebrand factor levels have been previously reported.[36,40] In addition, bariatric surgery also has positive effects on other factors which increase cardiovascular risk such as athersclerotic load, insulin sensitivity and left ventricular function.[31] Furthermore, post surgery weight reduction may improve physical activity, image and motivation to maintain healthier lifestyles.

In terms of absolute event rates, we found that there were lower fraction of events in the bariatric surgery group compared to non-operated overweight control groups for 
all outcomes. However, the mortality rate is still much higher than that of the general population aged 15 to 60 in America (0.5\%) and England (0.4\%) (WHO). We are also able to estimate, based on the mortality rate in a community cohort of severely obese patients,[14] a number needed to treat (NNT) of 59 (95\% CI 46-91) with bariatric surgery to prevent one death over a seven year follow-up period. This should be set in the context of statin therapy in patients with cardiovascular risk factors, where we have estimated (based on the pooled mortality rates in the meta-analysis by Brugts et al.) an NNT of 174 (95\% CI 110 - 428) to prevent one death with 4.1 years of continued statin intake.[41]

Our study has several strengths. We were able to include a total sample size of nearly 200,000 (29,208 cases of bariatric surgery and 166,200 nonsurgical controls) with a follow up period that ranged from 2 years to 14.7 years which allowed capture of a enough cardiovascular events. In addition, our analysis allowed for evaluation of the risk of myocardial infarction, stroke, cardiovascular events and mortality. We were also able to consider the effects of adjustment and study quality in our analyses.

\section{Study limitations}

Our study has several limitations. All the included studies were observational in nature as the randomized controlled trial of bariatric surgery did not capture sufficient cardiovascular events. Furthermore, there is high level of heterogeneity as there were different methods that were used to identify non-surgical controls. It is possible that in the absence of randomization patients may be selectively chosen for bariatric surgery because they are more likely to have positive outcomes after surgery. While some of the included studies did adjust for potential confounders it is possible that 
there are some unmeasured confounders which could not be fully accounted for. Moreover, the quality of the studies varied, and only three studies were considered to be of low to moderate risk of bias. Nevertheless, the mortality and cardiovascular benefits associated with bariatric surgery remained significant even after we excluded moderate-high risk studies from all the meta-analyses.

\section{Future studies}

Future research should be conducted to evaluate the long-term effects of bariatric surgery particularly through high-quality clinical trials such as the ongoing open randomized controlled trial, DiaSurg 2, which evaluates surgical vs. medical treatment of insulin dependent type 2 diabetes mellitus patients and follows participants for up for 8 years and measures outcomes such as cardiovascular death, myocardial infarction, non-fatal stroke.[42]

\section{Conclusions}

In conclusion, current observational studies provide consistent evidence that morbidly obese patients undergoing bariatric surgery have lower rates of myocardial infarction, stroke, cardiovascular events and mortality_compared to matched non surgical controls (mortality $3.6 \%$ vs. $11.4 \%$, cardiovascular events $2.4 \%$ vs. $4.0 \%$, myocardial infarction $1.3 \%$ vs. $2.5 \%$ and stroke $0.8 \%$ vs. $1.5 \%$ ). Whilst, our data does not infer a causal relationship, our analysis suggests that bariatric surgery may be beneficial particularly in morbidly obese patients at risk of future cardiovascular events.

Whether or not these reductions in clinical events are also observed in prospective randomized studies should be evaluated. 


\section{References}

[1] Stevens GA, Singh GM, Lu Y, et al. National, regional and global trends in adult overweight and obesity prevalences. Popul Health Metr 2012;10:22.

[2] Haslam DW, James WP. Obesity. Lancet 2005;366:1197-209.

[3] Kolotkin RL, Meter K, Williams GR. Quality of life and obesity. Obes Rev 2001;2:219-29.

[4] Daviglus ML, Liu K, Pirzada A. Relation of body mass index in young adulthood and middle age to Medicare expenditures in older age. JAMA 2004;292:2743-9.

[5] Eckel RH. Nonsurgical management of obesity in adults. $\mathrm{N}$ Engl J Med 2008;358:1941-50.

[6] De Maria EJ. Bariatric surgery for morbid obesity. N Engl J Med 2007; 356;21762183.

[7] Pontiroli AE, Morabito A. Long-term prevention of mortality in morbid obesity through bariatric surgery: a systematic review and meta-analysis of trials performed with gastric banding and gastric bypass. Ann Surg 2011;253;484-7.

[8] Vest AR Heneghan HM, Agarwal S, Schauer PR, Young JB. Bariatric surgery and cardiovascular outcomes: a systematic review. Heart 2012;98:1763-77.

[9] Athyros VG, Tzaiomalos K, Karaglannis A, Mikhailidis DP. Cardiovascular benefits of bariatric surgery in morbidly obese patients. Obes Rev 2011;12:515-24.

[10] Loke YK, Price D, Herxheimer A. Chapter 14: Adverse effects. In: Higgins JPT, Green S editors. Cochrane Handbook for Systematic Reviews of Interventions. Chichester (UK): John Wiley \& Sons; 2008.

[11] Ioannidis JP, Trikalinos TA. The appropriateness of asymmetry tests for publication bias in meta-analysis: a large survey. CMAJ 2007;176:1091-6.

[12] Davies HT, Crombie IK, Tavakoli M. When can odds ratios mislead? BMJ 1998;316:989-91.

[13] Higgins JP, Thompson SG, Deeks JJ, et al. Measuring inconsistency in metaanalysis. BMJ 2003;327:557-60.

[14] Adams TD, Gress RE, Smith SC, et al. Long-term mortality after gastric bypass surgery. N Engl J Med 2007;357:753-61.

[15] Adams TD, Davidson LE, Litwin SE, et al. Health benefits of gastric bypass surgery after 6 years. JAMA 2012;308:1122-1131. 
[16] Arteburn D, Bogart A, Coleman KJ, et al. Comparative effectiveness of bariatric surgery vs. nonsurgical treatment of type 2 diabetes among severely obese adults. Obes Res Clin Pract 2013;7:e258-e268.

[17] Busetto L, Mirabelli D, Petroni ML, et al. Comparative long-term mortality after laparoscopic adjustable gastric banding versus nonsurgical controls. Surg Obes Relat Dis 2007;3:496-502.

[18] Christou NV, Sampalis JS, Liberman M, et al. Surgery decreases long-term mortality, morbidity, and health care use in morbidly obese patients. Ann Surg 2004;240:416-424.

[19] Flum DR, Dellinger EP. Impact of gastric bypass operation on survival: a population-based analysis. J Am Coll Surg 2004;199:543-551.

[20] Gentileschi P, D'Eletto M, D'Ugo S, et al. Effect of bariatric surgery on comorbidities vs. medical treatment in a cohort of morbidly obese patients: a prospective study. Gastroenterology 2012;142 Supplement 1. S-1102.

[21] Johnson BL, Blackhurst DW, Latham BB, et al. Bariatric surgery is associated with a reduction in major macrovascular and microvascular complications in moderately to severely obese patients with type 2 diabetes. J Am Coll Surg 2013;216:545-558.

[22] Maciejewski ML, Livingston EH, Smith VA, et al. Survival among high-risk patients after bariatric surgery. JAMA 2011;305:2419-2426.

[23] Miranda W. Long-term mortality in patients undergoing bariatric surgery compared to patients managed non-operatively for morbid obesity. Eur Heart J 2012;33.

[24] Peeters A, O'Brien PE, Laurie C, et al. Substantial intentional weight loss and mortality in the severely obese. Ann Surg 2007;246:1028-1033.

[25] Scott JD, Johnson BL, Blackhurst DW, Bour ES. Does bariatric surgery reduce the risk of major cardiovascular events? A retrospective cohort study of morbidly obese surgical patients. Surg Obes Relat Dis 2013;9:32-41.

[26] Sjostrom L, Peltonen M, Jacobson P, et al. Bariatric surgery and long-term cardiovascular events. JAMA 2012;307:56-65.

[27] Sjostrom L. Review of the key results from the Swedish Obese Subjects (SOS) trial - a prospective controlled intervention study of bariatric surgery. J Intern Med 2013;273:219-234.

[28] Sowemimo OA, Yood SM, Courtney J, et al. Natural history of morbid obesity without surgical intervention. Surg Obes Relat Dis 2007;3:73-7.

[29] Gloy VL, Briel M, Bhatt DL, et al. Bariatric surgery versus non-surgical treatment for obesity. BMJ 2013;347:f5934. 
[30] Ricci C, Gaeta M, Rausa E, Macchitella Y, Bonavina L. Early impact of bariatric surgery on type II diabetes, hypertension, and hyperlipidaemia: A systematic review, meta-analysis and meta-regression of 6,587 patients. Obes Surg 2013; PMID:24214202.

[31] Ashrafian H, le Roux CW, Darzi A, Athanasiou T. Effects of bariatric surgery on cardiovascular function. Circulation 2008;118:2091-2102.

[32] Nijhuis J, van Dielen FM, Buurman WA, Greve JW. Ghrelin, leptin and insulin levels after restrictive surgery: a 2-year follow-up study. Obes Surg 2004;14:783-787.

[33] Santoro S, Milleo FQ, Malzoni CE, et al. Enterohormonal changes after digestive adaption: five-year results of a surgical proposal to treat obesity and associated disease. Obes Surg 2008;18:17-26.

[34] Dubey L, Hesong Z. Role of leptin in atherogenesis. Exp Clin Cardiol 2006;11:269-275.

[35] Burnett MS, Lee CW, Kinnaird TD, et al. The potential role of resistin in atherogenesis. Atherosclerosis 2005;182(2):241-8.

[36] Vazquez LA, Pazos F, Berrazueta JR, et al. Effects of changes in body weight and insulin resistance on inflammation and endothelial function in morbid obesity after bariatric surgery. J Clin Endocrinol Metab 2005;90:316-322.

[37] Pontiroli AE, Pizzocri P, Koprivec D, et al. Body weight and glucose metabolism have a different effect on circulating levels of ICAM-1, E-selectin, and endothelin-1 in humans. Eur J Endocrinol 2004;150:195-200.

[38] Nijhuis J, van Dielen FM, Fouraschen SM, et al. Endothelial activation markers and their key regulators after restrictive bariatric surgery. Obesity 2007;15:1395-1399.

[39] Demerath E, Towne B, Blangero J, Siervogel RM. The relationship of soluble ICAM-1, VCAM-1, P-selectin and E-selectin to cardiovascular disease risk factors in healthy men and women. Ann Hum Biol 2001;28:664-78.

[40] Uzun H, Zengin K, Taskin M, Aydin S, Simsek G, Dariyerli N. Changes in leptin, plasminogen activator factor and oxidative stress in morbidly obese patients following open and laparoscopic Swedish adjustable gastric banding. Obes Surg 2004;14:659-665.

[41] Brugts JJ, Yetgin T, Hoeks SE, et al. The benefit of statins in people without established cardiovascular disease but with cardiovascular risk factors: meta-analysis of randomised controlled trials. BMJ 2009;338:b2376.

[42] Kenngott HG, Clemens G, Gondan M, et al. DiaSurg 2 trial - surgical vs. medical treatment of insulin-dependent type 2 diabetes mellitus in patients with a body mass index between 26 and $35 \mathrm{~kg} / \mathrm{m} 2$ : study protocol of a randomized controlled multicenter trial - DRKS00004550. Trials 2013;14:183. 


\section{Table and Figure Legends}

Table 1: Study design, sample size and participants

Table 2: Quality assessment of included studies

Table 3: Treatment groups, follow up and results

Supplementary Table 1: Results of studies

Figure 1: Flow diagram of study selection

Figure 2: Meta-analyses of mortality risk after bariatric surgery as compared to no surgery

Figure 3: Meta-analysis of risk of myocardial infarction after bariatric surgery compared to no surgery

Figure 4: Meta-analysis of stroke risk after bariatric surgery as compared to no surgery

Figure 5: Meta-analyses of adverse cardiovascular events risk after bariatric surgery as compared to no surgery

Supplement Data 1: Search Strategy 
Table 1: Study design, sample size and participants

\begin{tabular}{|c|c|c|c|c|c|c|c|}
\hline Study & Design & Dates & Country & Sample size & Age & \% Male & Participants \\
\hline Adams 2007 & $\begin{array}{l}\text { Matched } \\
\text { retrospective } \\
\text { cohort study. }\end{array}$ & $\begin{array}{l}1984 \text { to } \\
2002 .\end{array}$ & Utah, USA. & $\begin{array}{l}7925 \text { surgery, } \\
7925 \text { control. }\end{array}$ & 39 & 16 & $\begin{array}{l}\text { Bariatric surgical patients matched to } \\
\text { severely obese controls (BMI } \geq 35 \text { ) based } \\
\text { on age, gender, BMI and year of } \\
\text { surgery/application. }\end{array}$ \\
\hline Adams 2012 & $\begin{array}{l}\text { Prospective } \\
\text { cohort study. }\end{array}$ & $\begin{array}{l}\text { July } 2000 \\
\text { to June } \\
2011 .\end{array}$ & Utah, USA. & $\begin{array}{l}418 \text { surgery, } \\
417 \text { (control } \\
\text { 1)and } 321 \\
\text { (control 2). }\end{array}$ & 45 & 18 & $\begin{array}{l}\text { Bariatric surgery and nonsurgical control } \\
\text { seeking bariatric surgery and those } \\
\text { recruited from Utah Health Family Tree } \\
\text { Program with BMI } \geq 35 \text {. }\end{array}$ \\
\hline $\begin{array}{l}\text { Arterburn } \\
2013\end{array}$ & $\begin{array}{l}\text { Retrospective } \\
\text { cohort study. }\end{array}$ & $\begin{array}{l}2005 \text { to } \\
2008 .\end{array}$ & $\begin{array}{l}\text { Minnesota, Seattle, } \\
\text { California, USA. }\end{array}$ & $\begin{array}{l}1395 \text { surgery, } \\
62,322 \text { control. }\end{array}$ & 49 & 27 & $\begin{array}{l}\text { Bariatric surgery and nonsurgical } \\
\text { treatment control both groups were } \\
\text { severely obese adults (BMI>35) with } \\
\text { type } 2 \text { diabetes. }\end{array}$ \\
\hline $\begin{array}{l}\text { Busetto } \\
2007\end{array}$ & $\begin{array}{l}\text { Matched } \\
\text { cohort study. }\end{array}$ & $\begin{array}{l}\text { Jan } 1994 \\
\text { to Dec } \\
2001 .\end{array}$ & Padova, Italy. & $\begin{array}{l}821 \text { surgery, } \\
821 \text { control. }\end{array}$ & 41 & 25 & $\begin{array}{l}\text { Surgical patients compared to gender, } \\
\text { age and BMI matched patients. }\end{array}$ \\
\hline $\begin{array}{l}\text { Christou } \\
2004\end{array}$ & $\begin{array}{l}\text { Matched } \\
\text { cohort study. }\end{array}$ & $\begin{array}{l}\text { Jan } 1986 \\
\text { to June } \\
2002 .\end{array}$ & Montreal, Canada & $\begin{array}{l}\text { 1,035 surgery, } \\
5,746 \text { control. }\end{array}$ & 46 & 36 & $\begin{array}{l}\text { Bariatric surgery compared to } \\
\text { nonsurgical treatment matched based on } \\
\text { age, gender and date of diagnosis of } \\
\text { morbid obesity. }\end{array}$ \\
\hline Flum 2004 & $\begin{array}{l}\text { Retrospective } \\
\text { cohort study. }\end{array}$ & $\begin{array}{l}1987 \text { to } \\
2001\end{array}$ & Washington, USA. & $\begin{array}{l}\text { 3,328 surgery, } \\
\text { 62,781 control. }\end{array}$ & 47 & 35 & $\begin{array}{l}\text { Surgical patients and patients of similar } \\
\text { age with diagnosis of obesity or morbid } \\
\text { obesity without surgery. }\end{array}$ \\
\hline $\begin{array}{l}\text { Gentileschi } \\
2012\end{array}$ & $\begin{array}{l}\text { Prospective } \\
\text { cohort study. }\end{array}$ & $\begin{array}{l}\text { Jan } 2003 \\
\text { to Nov } \\
2011 .\end{array}$ & Italy. & $\begin{array}{l}208 \text { surgery, } 81 \\
\text { not operated. }\end{array}$ & NA & 28 & $\begin{array}{l}\text { Bariatric surgery compared to } \\
\text { nonsurgical treatment. }\end{array}$ \\
\hline $\begin{array}{l}\text { Johnson } \\
2013\end{array}$ & $\begin{array}{l}\text { Retrospective } \\
\text { matched } \\
\text { cohort. }\end{array}$ & $\begin{array}{l}1996 \text { to } \\
2009 .\end{array}$ & South Carolina, USA. & $\begin{array}{l}\text { 2,580 surgery, } \\
13,371 \text { control. }\end{array}$ & 51 & 31 & $\begin{array}{l}\text { Bariatric surgery compared to } \\
\text { nonsurgical treatment and all patients } \\
\text { had type } 2 \text { diabetes and moderate to } \\
\text { severe obese adults. }\end{array}$ \\
\hline
\end{tabular}




\begin{tabular}{|c|c|c|c|c|c|c|c|}
\hline $\begin{array}{l}\text { Maciejewski } \\
2011\end{array}$ & $\begin{array}{l}\text { Retrospective } \\
\text { cohort study. }\end{array}$ & $\begin{array}{l}\text { Jan } 2000 \\
\text { to Dec } \\
2006 .\end{array}$ & $\begin{array}{l}\text { USA (Veterans Affairs } \\
\text { medical centers). }\end{array}$ & $\begin{array}{l}847 \text { surgery, } \\
847 \text { control. }\end{array}$ & 49 & 74 & $\begin{array}{l}\text { Bariatric surgery compared to } \\
\text { nonsurgical treatment with BMI > 35. }\end{array}$ \\
\hline $\begin{array}{l}\text { Miranda } \\
2012\end{array}$ & $\begin{array}{l}\text { Retrospective } \\
\text { cohort study. }\end{array}$ & $\begin{array}{l}1990 \text { to } \\
2009 .\end{array}$ & $\begin{array}{l}\text { Rochester, Minnesota, } \\
\text { USA. }\end{array}$ & $\begin{array}{l}\text { 2,020 surgery, } \\
\text { 2,907 control. }\end{array}$ & 56 & 30 & $\begin{array}{l}\text { Bariatric surgery compared to } \\
\text { nonsurgical treatment. Patients were }>18 \\
\text { years of age and had BMI }>35 \text {. }\end{array}$ \\
\hline $\begin{array}{l}\text { Peeters } \\
2007\end{array}$ & $\begin{array}{l}\text { Two cohort } \\
\text { observational } \\
\text { study. }\end{array}$ & $\begin{array}{l}\text { Jan } 1993 \\
\text { to Apr } \\
2005 . \\
\end{array}$ & Melbourne, Australia. & $\begin{array}{l}\text { 966 surgery, } \\
2,119 \text { control. }\end{array}$ & 53 & 23 & $\begin{array}{l}\text { Gastric banding patients compared to age } \\
\text { and BMI matched population cohort } \\
(\mathrm{BMI}>35) \text {. }\end{array}$ \\
\hline Scott 2013 & $\begin{array}{l}\text { Retrospective } \\
\text { cohort study. }\end{array}$ & $\begin{array}{l}\text { Jan } 1996 \\
\text { to Dec } \\
2008 .\end{array}$ & $\begin{array}{l}\text { Greenville, South Carolina, } \\
\text { USA. }\end{array}$ & $\begin{array}{l}\text { 4,747 surgery, } \\
\text { 4,393 control. }\end{array}$ & 54 & 20 & $\begin{array}{l}\text { Bariatric surgery compared to } \\
\text { orthopaedic and gastrointestinal surgery } \\
\text { control. Age } 40-79 \text { years with morbid } \\
\text { obesity. }\end{array}$ \\
\hline $\begin{array}{l}\text { Sjostrom } \\
2007 \text { and } \\
2012\end{array}$ & $\begin{array}{l}\text { Prospective } \\
\text { matched } \\
\text { cohort. }\end{array}$ & $\begin{array}{l}\text { Sept } 1987 \\
\text { to } 2005- \\
2009 .\end{array}$ & $\begin{array}{l}\text { Sweden ( } 25 \text { public surgical } \\
\text { departments and } 480 \\
\text { primary health care } \\
\text { centres). }\end{array}$ & $\begin{array}{l}\text { 2,010 surgery, } \\
\text { 2,037 control. }\end{array}$ & 48 & 29 & $\begin{array}{l}\text { Bariatric surgery compared to } \\
\text { nonsurgical treatment. Age } 37-60 \text { years } \\
\text { and BMI }>34 \text { for men and }>38 \text { for } \\
\text { women. }\end{array}$ \\
\hline $\begin{array}{l}\text { Sowemimo } \\
2007\end{array}$ & $\begin{array}{l}\text { Retrospective } \\
\text { cohort study. }\end{array}$ & $\begin{array}{l}1997 \text { to } \\
2006 .\end{array}$ & Connecticut, USA. & $\begin{array}{l}908 \text { surgery, } \\
112 \text { control. }\end{array}$ & 44 & 27 & $\begin{array}{l}\text { Bariatric surgery compared to } \\
\text { nonsurgical treatment. }\end{array}$ \\
\hline
\end{tabular}


Table 2: Quality assessment of included studies

\begin{tabular}{|c|c|c|c|c|c|c|c|}
\hline Study & Ascertainment of controls. & $\begin{array}{l}\text { Ascertainment of } \\
\text { surgery. }\end{array}$ & Ascertainment of outcomes. & $\begin{array}{l}\text { Lost to follow } \\
\text { up. }\end{array}$ & $\begin{array}{l}\text { Use of propensity matching or } \\
\text { adjustment for confounding. }\end{array}$ & $\begin{array}{l}\text { Generalizability of } \\
\text { findings }\end{array}$ & Risk of bias. \\
\hline Adams 2007 & $\begin{array}{l}\text { Yes. Self-reported BMI } \\
\geq 35 \text { randomly selected } \\
\text { from among applicants for } \\
\text { driver's license or } \\
\text { identification card. }\end{array}$ & $\begin{array}{l}\text { No. Unclear } \\
\text { description of how } \\
\text { ascertained. }\end{array}$ & $\begin{array}{l}\text { Yes. Death is obtained from the } \\
\text { National Death Index. }\end{array}$ & $\begin{array}{l}\text { Unclear. No } \\
\text { loss to follow } \\
\text { up reported. }\end{array}$ & $\begin{array}{l}\text { Yes. Matching for sex, BMI, self- } \\
\text { reported BMI, age and year. }\end{array}$ & $\begin{array}{l}\text { Yes. Likely that } \\
\text { controls are } \\
\text { potential candidates } \\
\text { for surgery. }\end{array}$ & Moderate \\
\hline Adams 2012 & $\begin{array}{l}\text { Yes. All participants } \\
\text { underwent a baseline } \\
\text { examination at the } \\
\text { University of Utah Center. }\end{array}$ & $\begin{array}{l}\text { Yes. All participants } \\
\text { underwent a baseline } \\
\text { examination at the } \\
\text { University of Utah } \\
\text { Center. }\end{array}$ & $\begin{array}{l}\text { Yes. Death is obtained from the } \\
\text { National Death Index. }\end{array}$ & $\begin{array}{l}\text { No. } 130 \text { did } \\
\text { not complete } \\
\text { examination at } \\
6 \text { years. }\end{array}$ & No. Crude, unadjusted results. & $\begin{array}{l}\text { Yes. Likely that } \\
\text { controls are } \\
\text { potential candidates } \\
\text { for surgery. }\end{array}$ & $\begin{array}{l}\text { Moderate- } \\
\text { high. }\end{array}$ \\
\hline $\begin{array}{l}\text { Arterburn } \\
2013\end{array}$ & $\begin{array}{l}\text { Yes. Identification from } \\
\text { electronic medical records. }\end{array}$ & $\begin{array}{l}\text { Yes. Identification } \\
\text { from ICD-9 codes } \\
\text { and CPT-4 } \\
\text { procedure codes. }\end{array}$ & $\begin{array}{l}\text { Yes. Death ascertained from medical } \\
\text { databases and linking to stat death } \\
\text { indices in California and Minnesota. }\end{array}$ & $\begin{array}{l}\text { Unclear, not } \\
\text { reported. }\end{array}$ & $\begin{array}{l}\text { Yes. Unclear which adjusted } \\
\text { model used but would have at least } \\
\text { had site, gender, age, year, years } \\
\text { since diabetes diagnosed, HbA1c, } \\
\text { use of diabetic medications. }\end{array}$ & $\begin{array}{l}\text { No. Only } \\
\text { generalizable to } \\
\text { diabetes patients. }\end{array}$ & Moderate. \\
\hline $\begin{array}{l}\text { Busetto } \\
2007\end{array}$ & $\begin{array}{l}\text { Yes. morbidly obese } \\
\text { patients enrolled at } 6 \\
\text { tertiary obesity care centers } \\
\text { not using bariatric surgery. }\end{array}$ & $\begin{array}{l}\text { Yes. Obese patients } \\
\text { undergoing surgery } \\
\text { at a single centre. }\end{array}$ & $\begin{array}{l}\text { Yes. Patients were seen regularly in } \\
\text { outpatient basis. }\end{array}$ & $\begin{array}{l}\text { No. } 41 \\
\text { unknown vital } \\
\text { status. }\end{array}$ & $\begin{array}{l}\text { Yes. Adjusted for gender, age } \\
\text { class, and BMI class. }\end{array}$ & $\begin{array}{l}\text { Yes. Likely that } \\
\text { controls are } \\
\text { potential candidates } \\
\text { for surgery. }\end{array}$ & Moderate. \\
\hline $\begin{array}{l}\text { Christou } \\
2004\end{array}$ & $\begin{array}{l}\text { Yes. Use of provincial } \\
\text { health insurance database. }\end{array}$ & $\begin{array}{l}\text { Yes. Use of } \\
\text { provincial health } \\
\text { insurance database. }\end{array}$ & $\begin{array}{l}\text { Yes. In surgical cohort, vital status } \\
\text { was mainly determined as part of the } \\
\text { routine clinical follow up by direct } \\
\text { visual or telephone interview. } \\
\text { Interviews with the Town Office of } \\
\text { the municipality of the most recent } \\
\text { residence. Death certificates were } \\
\text { obtained form the Local Health } \\
\text { Authorities of the municipalities. }\end{array}$ & $\begin{array}{l}\text { Unclear. Not } \\
\text { reported. }\end{array}$ & $\begin{array}{l}\text { No. Matched for age, gender and } \\
\text { duration of follow up but not } \\
\text { adjusted. }\end{array}$ & $\begin{array}{l}\text { Yes. Likely that } \\
\text { controls are } \\
\text { potential candidates } \\
\text { for surgery. }\end{array}$ & $\begin{array}{l}\text { Moderate- } \\
\text { high. }\end{array}$ \\
\hline Flum 2004 & $\begin{array}{l}\text { Yes. Identification from } \\
\text { ICD-9 codes and } \\
\text { Washington State } \\
\text { Comprehensive Hospital } \\
\text { Abstract Reporting System } \\
\text { reports. }\end{array}$ & $\begin{array}{l}\text { Yes. Identification } \\
\text { from ICD-9 codes. }\end{array}$ & $\begin{array}{l}\text { Yes. Mortality derived from } \\
\text { Washington State vital records } \\
\text { database. }\end{array}$ & $\begin{array}{l}\text { Survival } \\
\text { analysis was } \\
\text { based on } \\
\text { patients who } \\
\text { were alive } \\
\text { from }>12 \\
\text { months after } \\
\text { the procedure. }\end{array}$ & $\begin{array}{l}\text { Yes. Adjusted for age, gender and } \\
\text { comorbidity index. }\end{array}$ & $\begin{array}{l}\text { Yes. Likely that } \\
\text { controls are } \\
\text { potential candidates } \\
\text { for surgery. }\end{array}$ & Moderate. \\
\hline
\end{tabular}




\begin{tabular}{|c|c|c|c|c|c|c|c|}
\hline & & & & $\begin{array}{l}\text { Unclear loss to } \\
\text { follow-up. }\end{array}$ & & & \\
\hline $\begin{array}{l}\text { Gentileschi } \\
2012\end{array}$ & $\begin{array}{l}\text { Unclear. Likely reliable } \\
\text { because prospective study. }\end{array}$ & Unclear. & Unclear. & $\begin{array}{l}\text { Unclear. Not } \\
\text { reported. }\end{array}$ & No. Crude, unadjusted results. & $\begin{array}{l}\text { Yes. Likely that } \\
\text { controls are } \\
\text { potential candidates } \\
\text { for surgery. }\end{array}$ & $\begin{array}{l}\text { Moderate- } \\
\text { high }\end{array}$ \\
\hline $\begin{array}{l}\text { Johnson } \\
2013\end{array}$ & $\begin{array}{l}\text { Yes. Selected from uniform } \\
\text { billing database. }\end{array}$ & $\begin{array}{l}\text { Yes. Identification } \\
\text { from ICD-9 codes. }\end{array}$ & $\begin{array}{l}\text { Yes. Death obtained from South } \\
\text { Carolina Department of Health and } \\
\text { Environmental Control. }\end{array}$ & $\begin{array}{l}\text { Yes. } 64 \text { lost to } \\
\text { follow up. }\end{array}$ & $\begin{array}{l}\text { Propensity score adjusted data } \\
\text { available for composite } \\
\text { macrovascular events but not for } \\
\text { specific outcomes. }\end{array}$ & $\begin{array}{l}\text { No. Only } \\
\text { generalizable to } \\
\text { diabetes patients. }\end{array}$ & $\begin{array}{l}\text { Moderate. } \\
\text { (low- } \\
\text { moderate } \\
\text { for } \\
\text { composite } \\
\text { outcomes) }\end{array}$ \\
\hline $\begin{array}{l}\text { Maciejewski } \\
2011\end{array}$ & $\begin{array}{l}\text { Yes. Identified from } \\
\text { Veterans Affairs registry. }\end{array}$ & $\begin{array}{l}\text { Yes. Identified from } \\
\text { a database using } \\
\text { ICD-9 and Current } \\
\text { Procedural } \\
\text { Terminology-4 } \\
\text { codes. }\end{array}$ & $\begin{array}{l}\text { Yes. Nurse contacted the patient or } \\
\text { family } 30 \text { days after the operation } \\
\text { and updated mortality was checked } \\
\text { against the Veteran's Affairs vital } \\
\text { status database. }\end{array}$ & $\begin{array}{l}\text { Not applicable } \\
\text { as } \\
\text { retrospective } \\
\text { matched } \\
\text { analysis. }\end{array}$ & $\begin{array}{l}\text { Yes. Adjusted for age, sex, self- } \\
\text { reported race, marital status, BMI, } \\
\text { comorbidity burden and Veterans } \\
\text { Integrated Service Network of } \\
\text { residence. }\end{array}$ & $\begin{array}{l}\text { Yes. Likely that } \\
\text { controls are } \\
\text { potential candidates } \\
\text { for surgery. }\end{array}$ & $\begin{array}{l}\text { Low- } \\
\text { moderate }\end{array}$ \\
\hline $\begin{array}{l}\text { Miranda } \\
2012\end{array}$ & $\begin{array}{l}\text { Yes. Patients in nutrition } \\
\text { clinic at Mayo clinic. }\end{array}$ & $\begin{array}{l}\text { Yes. Patients in } \\
\text { nutrition clinic at } \\
\text { Mayo clinic. }\end{array}$ & $\begin{array}{l}\text { Yes. Data from Mayo Clinic registry } \\
\text { database and Accurint (web-based } \\
\text { resource). }\end{array}$ & $\begin{array}{l}\text { Unclear. Not } \\
\text { reported. }\end{array}$ & Yes. Adjusted for propensity score. & $\begin{array}{l}\text { Yes. Likely that } \\
\text { controls are } \\
\text { potential candidates } \\
\text { for surgery. }\end{array}$ & Moderate \\
\hline $\begin{array}{l}\text { Peeters } \\
2007\end{array}$ & $\begin{array}{l}\text { Yes. Data recorded in face } \\
\text { to face interview and } \\
\text { information collected } \\
\text { through questionnaire. }\end{array}$ & $\begin{array}{l}\text { Yes. Data recorded } \\
\text { in interview and } \\
\text { information } \\
\text { collected through } \\
\text { questionnaire. } \\
\end{array}$ & $\begin{array}{l}\text { Yes. Annual follow-up visits to } \\
\text { clinic or telephone call to confirm } \\
\text { vital status. These were matched to } \\
\text { Victoria Registry of Births, Deaths } \\
\text { and Marriages for matching. }\end{array}$ & $\begin{array}{l}\text { Yes. } 26 \text { lost to } \\
\text { follow up. }\end{array}$ & $\begin{array}{l}\text { Yes. Adjusted for age, sex and } \\
\text { initial BMI. }\end{array}$ & $\begin{array}{l}\text { Yes. Likely that } \\
\text { controls are } \\
\text { potential candidates } \\
\text { for surgery. }\end{array}$ & Moderate \\
\hline Scott 2013 & $\begin{array}{l}\text { Yes. Ascertained by ICD-9 } \\
\text { codes for orthopaedic and } \\
\text { gastrointestinal procedure } \\
\text { from the South Carolina } \\
\text { Office of Research and } \\
\text { Statistics. }\end{array}$ & $\begin{array}{l}\text { Yes. Ascertained by } \\
\text { ICD-9 codes for } \\
\text { primary bariatric } \\
\text { procedure from the } \\
\text { South Carolina } \\
\text { Office of Research } \\
\text { and Statistics. }\end{array}$ & $\begin{array}{l}\text { Yes. Death obtained from South } \\
\text { Carolina Department of Health and } \\
\text { Environmental Control's Office of } \\
\text { Vital Statistics. }\end{array}$ & $\begin{array}{l}\text { No. } 1424 \\
\text { excluded (9\%). }\end{array}$ & $\begin{array}{l}\text { Adjusted for age, gender and } \\
\text { history of cardiovascular disease, } \\
\text { hyperlipidaemia, and diabetes } \\
\text { mellitus. }\end{array}$ & $\begin{array}{l}\text { No. Surgical } \\
\text { controls used. }\end{array}$ & $\begin{array}{l}\text { Low- } \\
\text { Moderate. }\end{array}$ \\
\hline $\begin{array}{l}\text { Sjostrom } \\
2007 \text { and } \\
2012\end{array}$ & $\begin{array}{l}\text { Yes. Ascertainment at } \\
\text { baseline examination. }\end{array}$ & $\begin{array}{l}\text { Yes. Ascertainment } \\
\text { at baseline } \\
\text { examination. }\end{array}$ & $\begin{array}{l}\text { Yes. Physical examination and } \\
\text { questionnaires used to follow up } \\
\text { patients. }\end{array}$ & $\begin{array}{l}\text { Yes. 99\% } \\
\text { follow up rate. }\end{array}$ & $\begin{array}{l}\text { Yes. Adjusted for sex, age, MI, } \\
\text { stroke, diabetes, smoking, lipid } \\
\text { lowering medication, } \\
\text { antihypertensives, insulin, BMI, } \\
\text { waist, hip, systolic blood pressure, }\end{array}$ & $\begin{array}{l}\text { Yes. Likely that } \\
\text { controls are } \\
\text { potential candidates } \\
\text { for surgery. }\end{array}$ & $\begin{array}{l}\text { Low- } \\
\text { moderate }\end{array}$ \\
\hline
\end{tabular}




\begin{tabular}{|c|c|c|c|c|c|c|c|}
\hline & & & & & $\begin{array}{l}\text { total cholesterol, HDL cholesterol } \\
\text { and triglycerides. }\end{array}$ & & \\
\hline $\begin{array}{l}\text { Sowemimo } \\
2007\end{array}$ & $\begin{array}{l}\text { Yes. Telephone interviews } \\
\text { were conducted. }\end{array}$ & $\begin{array}{l}\text { Yes. Bariatric } \\
\text { database review. }\end{array}$ & $\begin{array}{l}\text { Yes. Using Social Security Death } \\
\text { Index. }\end{array}$ & $\begin{array}{l}\text { Missing data } \\
\text { on } 165 \text { patients } \\
\text { (>10\% of } \\
\text { cohort). }\end{array}$ & $\begin{array}{l}\text { Yes. Adjusted for age, gender and } \\
\text { body mass index. }\end{array}$ & $\begin{array}{l}\text { Yes. Likely that } \\
\text { controls are } \\
\text { potential candidates } \\
\text { for surgery. }\end{array}$ & $\begin{array}{l}\text { Moderate- } \\
\text { high.. }\end{array}$ \\
\hline
\end{tabular}

ICD=International Classification of Disease, MI=myocardial infarction, BMI=body mass index, HDL=high density lipoproteins 
Table 3: Treatment groups, follow up and results

\begin{tabular}{|c|c|c|c|c|}
\hline Study & Type of surgery & Type of control & Follow up & Outcomes \\
\hline Adams 2007 & $\begin{array}{l}\text { Roux-en-Y gastric bypass } \\
\text { surgery performed by a single } \\
\text { Utah surgical practice of six } \\
\text { experienced surgeons. }\end{array}$ & $\begin{array}{l}\text { Randomly selected driving } \\
\text { license applicants with self- } \\
\text { reported BMI of } \geq 35 \text {. }\end{array}$ & Mean 7.1 to 7.8 years. & $\begin{array}{l}\text { Matched cohort events: Death 213/7925 vs. } \\
\text { 321/7925 Adjusted HR } 0.60(0.45-0.67) \text {. } \\
\text { Death according to cause: } \\
\text { CAD 15/7925 vs. 33/7925 Adjusted HR } 0.41 \\
(0.21-0.78) . \\
\text { Stroke } 7 / 7925 \text { vs. } 11 / 7925 \text { Adjusted HR } 0.43 \\
(0.14-1.30) \text {, } \\
\text { CV death 55/7925 vs.. } 104 / 7925 \text {, Adjusted HR } \\
0.51(0.36-0.73)\end{array}$ \\
\hline Adams 2012 & $\begin{array}{l}\text { Roux-en-Y gastric bypass } \\
\text { surgery performed at the same } \\
\text { surgical center. }\end{array}$ & $\begin{array}{l}\text { Non-intervened severely obese } \\
\text { controls seeking surgery. }\end{array}$ & Median follow up 5.8 years. & $\begin{array}{l}\text { Crude events death } 12 / 418 \text { vs. } 17 / 738 . \\
\text { Unadjusted RR } 1.25(0.60-2.58)\end{array}$ \\
\hline $\begin{array}{l}\text { Arterburn } \\
2013\end{array}$ & $\begin{array}{l}\text { Bariatric surgery based on } \\
\text { ICD-9 and CPT- } 4 \text { procedure } \\
\text { codes. }\end{array}$ & $\begin{array}{l}\text { Nonsurgical usual medical } \\
\text { care. }\end{array}$ & Up to 2 years. & $\begin{array}{l}\text { Death: } 5 / 1395 \text { vs. } 484 / 62322 \text {, adjusted HR } 0.54 \\
(0.22-1.23) .\end{array}$ \\
\hline $\begin{array}{l}\text { Busetto } \\
2007\end{array}$ & $\begin{array}{l}\text { Lap-Band Adjustable Gastric } \\
\text { Banding System. }\end{array}$ & $\begin{array}{l}\text { Morbidly obese patients seen } \\
\text { in outpatients seeking } \\
\text { treatment for obesity. }\end{array}$ & Mean 5.6 to 7.2 years. & $\begin{array}{l}\text { Death: } 8 / 821 \text { vs. } 32 / 821 \text {, adjusted RR } 0.36 \\
(0.16-0.79) .\end{array}$ \\
\hline $\begin{array}{l}\text { Christou } \\
2004\end{array}$ & $\begin{array}{l}\text { Open Roux en Y gastric } \\
\text { bypass, vertical banded } \\
\text { gastroplasty and laparoscopic } \\
\text { RY gastric bypass. }\end{array}$ & $\begin{array}{l}\text { Controls with morbid obesity } \\
\text { on ICD9 codes for treatment in } \\
\text { hospital, treatment by a } \\
\text { physician or as an indication } \\
\text { for prescription, as well as } \\
\text { never having surgery for the } \\
\text { treatment for severe obesity. }\end{array}$ & $\begin{array}{l}\text { Mean } 2.5-2.6 \text { year but } \\
\text { outcomes followed up to } 5 \\
\text { years. }\end{array}$ & $\begin{array}{l}\text { Death: } n=7(0.68 \%) \text { vs. } n=354(6.17 \%) \text {, } \\
\text { unadjusted relative risk reduction } 0.11 \text { (0.04- } \\
0.27) \text {. }\end{array}$ \\
\hline Flum 2004 & Gastric bypass. & $\begin{array}{l}\text { Hospital diagnosis of morbid } \\
\text { obesity. }\end{array}$ & Follow up 15 years. & Death adjusted HR 0.67 (0.54-0.85). \\
\hline $\begin{array}{l}\text { Gentileschi } \\
2012\end{array}$ & $\begin{array}{l}\text { Laparoscopic gastric banding, } \\
\text { laparoscopic sleeve }\end{array}$ & Non-operated controls. & 29.2 to 38.2 months. & Crude events death $1 / 208$ vs. $4 / 81$. \\
\hline
\end{tabular}




\begin{tabular}{|c|c|c|c|c|}
\hline & $\begin{array}{l}\text { gastrectomy and laparoscopic } \\
\text { gastric banding. }\end{array}$ & & & \\
\hline $\begin{array}{l}\text { Johnson } \\
2013\end{array}$ & $\begin{array}{l}\text { Bariatric surgical patients } \\
\text { identified by primary ICD-9 } \\
\text { code. }\end{array}$ & $\begin{array}{l}\text { Control patients were } \\
\text { moderately to severely obese } \\
\text { patients with T2DM not } \\
\text { undergoing a bariatric } \\
\text { procedure. } \\
\end{array}$ & $\begin{array}{l}\text { Median follow up median of } \\
19.0 \text { to } 21.2 \text { months. }\end{array}$ & $\begin{array}{l}\text { Macrovascular event (MI, stroke, death) } \\
\text { propensity matched adjusted HR } 0.32(0.19- \\
0.54) \text {. Crude events MI 8/2580 vs. } 241 / 13371 \text {, } \\
\text { stroke } 11 / 2580 \text { vs. } 214 / 13371 \text {, death } 41 / 2580 \\
\text { vs. } 985 / 13371 \text {. }\end{array}$ \\
\hline $\begin{array}{l}\text { Maciejewski } \\
2011\end{array}$ & Batriatric procedures. & Nonsurgical controls. & Mean 6.7 years. & Death adjusted HR 0.94 (0.64-1.39). \\
\hline $\begin{array}{l}\text { Miranda } \\
2012\end{array}$ & $\begin{array}{l}\text { First bariatric procedure, 95\% } \\
\text { Roux-en-Y gastric bypass. }\end{array}$ & $\begin{array}{l}\text { Non-operative management } \\
\text { for obesity at Mayo Clinic. }\end{array}$ & $\begin{array}{l}\text { Follow up time of } 5.9 \text { to } 8.5 \\
\text { years. }\end{array}$ & Death adjusted HR 0.76 (0.60-0.96). \\
\hline $\begin{array}{l}\text { Peeters } \\
2007\end{array}$ & $\begin{array}{l}\text { Laparoscopic adjustable } \\
\text { gastric banding. }\end{array}$ & $\begin{array}{l}\text { Patients were a community } \\
\text { control cohort. }\end{array}$ & $\begin{array}{l}\text { Median follow up } 1 \text { month to } \\
14.6 \text { years. Follow up } \\
\text { censored at } 5 \text { and } 10 \text { years. } \\
\end{array}$ & Death adjusted HR 0.28 (0.10-0.85). \\
\hline Scott 2013 & $\begin{array}{l}\text { Bariatric surgery coded as } \\
\text { ICD-9 codes } 44.38,44.39 \text { and } \\
44.95 \text {. }\end{array}$ & $\begin{array}{l}\text { Surgical controls with } \\
\text { orthopaedic procedures and } \\
\text { gastrointestinal procedures. }\end{array}$ & Mean of 13.7 to 25.8 months. & $\begin{array}{l}\text { Adjusted HR after pooling both control arms: } \\
\text { MI: } 0.54(0.44-0.67) \\
\text { Stroke: } 0.59(0.37-0.95) \\
\text { Death: } 0.60(0.34-1.07) \\
\text { CV composite (MI, stroke, death): } 0.59 \text { (0.40 - } \\
0.88)\end{array}$ \\
\hline $\begin{array}{l}\text { Sjostrom } \\
2007 \text { and } \\
2012\end{array}$ & $\begin{array}{l}\text { Nonadjustable or adjustable } \\
\text { banding, vertical banded } \\
\text { gastroplasty and gastric } \\
\text { bypass surgery. }\end{array}$ & $\begin{array}{l}\text { Obese patients had customary } \\
\text { treatment for obesity. }\end{array}$ & $\begin{array}{l}\text { Mortality follow up mean } \\
10.9 \text { years.CV events median } \\
\text { follow up } 14.7 \text { years. }\end{array}$ & $\begin{array}{l}\text { Adjusted HR } \\
\text { Death } 0.71 \text { (0.54-0.92). } \\
\text { Cardiovascular events (fatal or non-fatal MI } \\
\text { and stroke) } 0.67 \text { (0.54-0.83), } \\
\text { MI 0.71 (0.54-0.94), } \\
\text { Stroke adjusted HR } 0.66(0.49-0.90) \text {. }\end{array}$ \\
\hline $\begin{array}{l}\text { Sowemimo } \\
2007\end{array}$ & $\begin{array}{l}\text { Roux-en-Y gastric bypass, } \\
\text { except } 7 \text { cases of adjustable } \\
\text { gastric banding. }\end{array}$ & Non-operated controls. & Unclear. & Death adjusted HR 0.18 (0.09-0.35). \\
\hline
\end{tabular}

MI=myocardial infarction, ICD=International Classification of Disease, HR=hazard ratio, RR=relative risk 
Supplementary Table 1: Results of studies

\begin{tabular}{|c|c|c|c|c|c|c|}
\hline Study & $\begin{array}{l}\text { Surgical } \\
\text { group }\end{array}$ & $\begin{array}{l}\text { Control } \\
\text { group }\end{array}$ & $\begin{array}{l}\text { Deaths in surgical vs. } \\
\text { control. }\end{array}$ & $\begin{array}{l}\text { CV composite in } \\
\text { surgical vs. control. }\end{array}$ & $\begin{array}{l}\text { MI in surgical vs. } \\
\text { control. }\end{array}$ & $\begin{array}{l}\text { Stroke in surgical vs. } \\
\text { control. }\end{array}$ \\
\hline Adams 2007 & 7,925 & 7925 & $\begin{array}{l}213 / 7925 \text { vs. } 321 / 7925, \\
\text { adjusted HR } 0.60(0.45- \\
0.67)\end{array}$ & $\begin{array}{l}\text { 55/7925 vs. 104/7925 } \\
\text { Adjusted HR 0.51 (0.36 } \\
-0.73)\end{array}$ & $\begin{array}{l}\text { 15/7925 vs. 33/7925, } \\
\text { adjusted HR } 0.41 \text { (0.21- } \\
0.78)\end{array}$ & $\begin{array}{l}\text { 7/7925 vs. 11/7925, } \\
\text { adjusted HR } 0.51(0.36- \\
0.73)\end{array}$ \\
\hline Adams 2012 & 418 & $\begin{array}{l}417 \\
\text { control } 1 \\
\text { and } 321 \\
\text { control } 2 \\
\end{array}$ & $\begin{array}{l}\text { 12/418 vs. 17/738, } \\
\text { unadjusted RR } 1.25 \\
(0.60-2.58)\end{array}$ & & & \\
\hline Arterburn 2013 & 1395 & 62,322 & $\begin{array}{l}\text { 5/1395 vs. 484/62322, } \\
\text { adjusted HR 0.54 (0.22- } \\
1.23)\end{array}$ & & & \\
\hline Busetto 2007 & 821 & 821 & $\begin{array}{l}\text { 8/821 vs. 32/821, adjusted } \\
\text { RR } 0.36(0.16-0.79)\end{array}$ & & & \\
\hline Christou 2004 & 1,035 & 5,746 & $\begin{array}{l}\text { 7/1035 vs. 354/5746, } \\
\text { unadjusted RR reduction } \\
0.11(0.04-0.27)\end{array}$ & & & \\
\hline $\begin{array}{l}\text { Gentileschi } \\
2012\end{array}$ & 208 & 81 & $1 / 208$ vs. $4 / 81$ & & & \\
\hline Johnson 2013 & 2,580 & 13,371 & $\begin{array}{l}41 / 2580 \text { vs. } 985 / 13371 \\
\text { Crude OR } 0.20(0.15- \\
0.27)\end{array}$ & $\begin{array}{l}\text { 19/2580 vs. 455/13371 } \\
\text { Adjusted HR } 0.32 \text { (0.19- } \\
0.54)\end{array}$ & $\begin{array}{l}\text { 8/2580 vs. } 241 / 13371 \\
\text { Crude OR } 0.17(0.08-0.35)\end{array}$ & $\begin{array}{l}\text { 11/2580 vs. 214/13371 } \\
\text { Crude OR } 0.26(0.14- \\
0.48)\end{array}$ \\
\hline $\begin{array}{l}\text { Maciejewski } \\
2011\end{array}$ & 847 & 847 & $\begin{array}{l}\text { 6.7\% (57/847) vs. } 12.8 \% \\
\text { (108/847), adjusted HR } \\
0.94(0.64-1.39) \\
\end{array}$ & & & \\
\hline Miranda 2012 & 2,020 & 2,907 & $\begin{array}{l}\text { 109/2020 vs. 304/2907, } \\
\text { adjusted HR } 0.76(0.60- \\
0.96)\end{array}$ & & & \\
\hline
\end{tabular}




\begin{tabular}{|c|c|c|c|c|c|c|}
\hline Peeters 2007 & 966 & 2,119 & $\begin{array}{l}\text { 4/966 vs. 225/2119, } \\
\text { adjusted HR } 0.28(0.10- \\
0.85)\end{array}$ & & & \\
\hline Scott 2013 & 4,747 & $\begin{array}{l}3066 \\
\text { control } 1 \\
\text { and } 1327 \\
\text { control } 2\end{array}$ & $\begin{array}{l}82 / 4747 \text { vs. } 215 / 3066 \text { vs. } \\
\text { 143/1327, adjusted HR } \\
0.54(0.44-0.67)\end{array}$ & $\begin{array}{l}\text { 99/4747 vs. } 234 / 3066 \text { vs. } \\
\text { 116/1327, adjusted HR } \\
0.59(0.40-0.88)\end{array}$ & $\begin{array}{l}\text { 81/4747 vs. } 186 / 3066 \text { vs. } \\
95 / 1327, \text { adjusted HR } 0.54 \\
(0.44-0.67)\end{array}$ & $\begin{array}{l}\text { 18/4747 vs. } 48 / 3066 \text { vs. } \\
\text { 21/1327, adjusted HR } \\
0.59(0.37-0.95)\end{array}$ \\
\hline $\begin{array}{l}\text { Sjostrom } 2007 \\
\text { and } 2012\end{array}$ & 2,010 & 2,037 & $\begin{array}{l}\text { 101/2010 vs. 129/2037, } \\
\text { adjusted HR } 0.71(0.54- \\
0.92)\end{array}$ & $\begin{array}{l}\text { 234/2010 vs. 199/2037, } \\
\text { adjusted HR } 0.67 \text { (0.54- } \\
0.83)\end{array}$ & $\begin{array}{l}\text { 122/2010 vs. 136/2037, } \\
\text { adjusted HR } 0.71(0.54- \\
0.94)\end{array}$ & 93/2010 vs. $111 / 2037$ \\
\hline $\begin{array}{l}\text { Sowemimo } \\
2007\end{array}$ & 908 & 112 & $\begin{array}{l}2.9 \%(26 / 908) \text { vs. } 14.3 \% \\
\text { (16/112), adjusted HR } \\
0.18(0.09-0.35)\end{array}$ & & & \\
\hline
\end{tabular}


Figure 1: Flow diagram of study selection

Search of MEDLINE and EMBASE

yielded 2,764 potentially relevant studies.

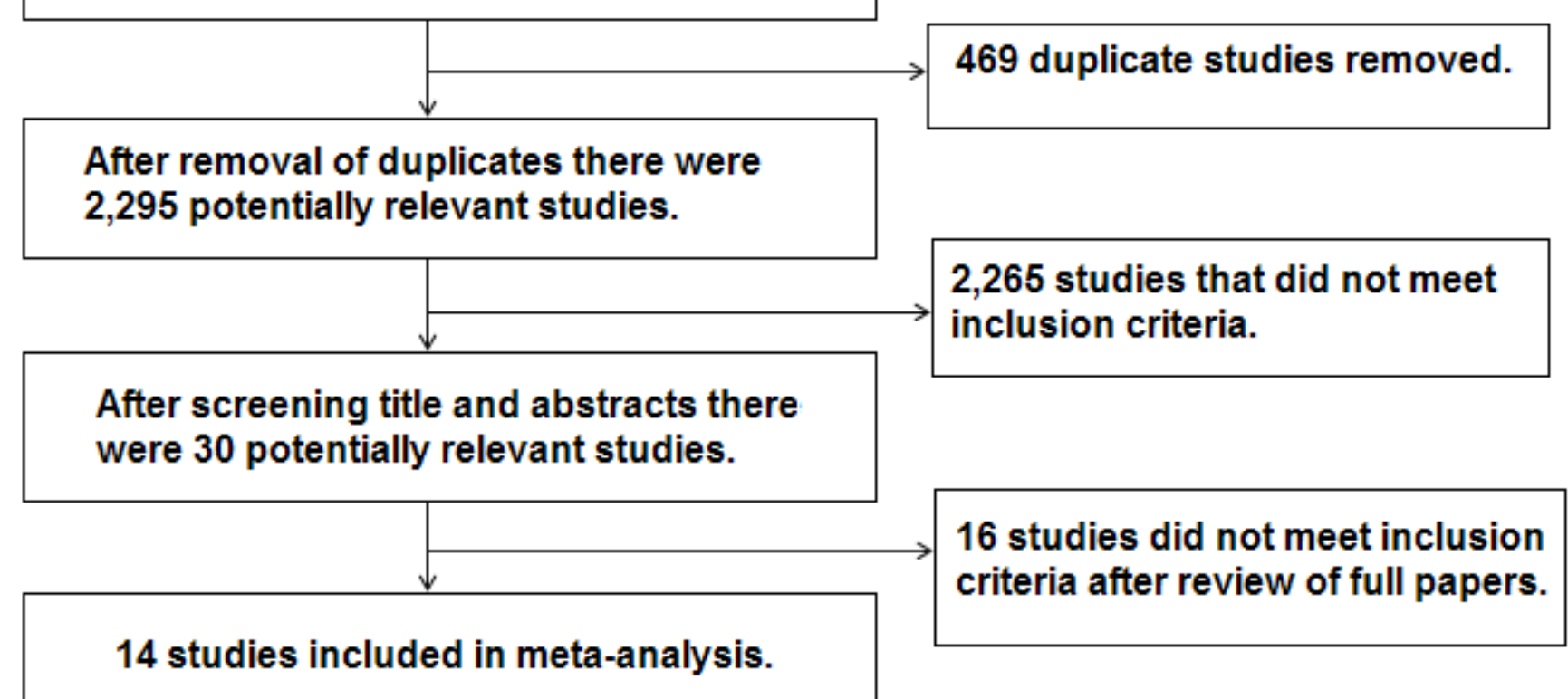


Figure 2: Meta-analyses of mortality risk after bariatric surgery as compared to no surgery

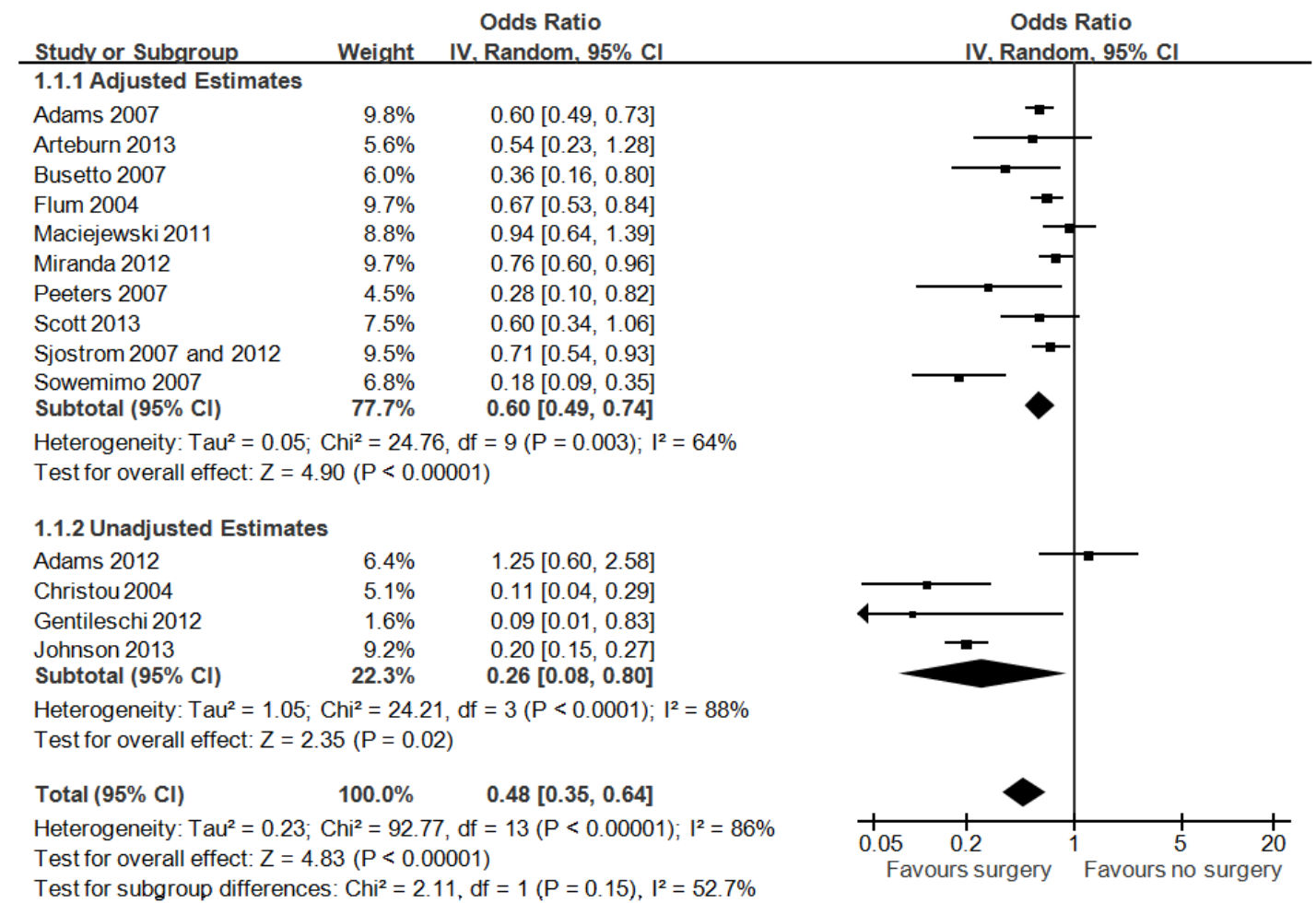


Figure 3: Meta-analysis of risk of myocardial infarction after bariatric surgery compared to no surgery

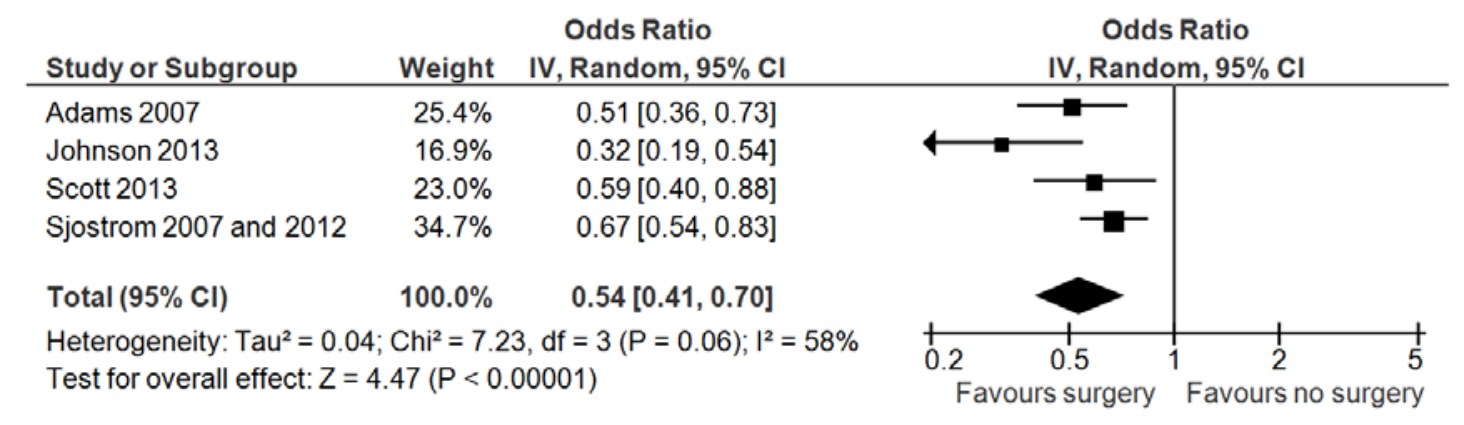


Figure 4: Meta-analysis of stroke risk after bariatric surgery as compared to no surgery

\begin{tabular}{|c|c|c|c|c|c|}
\hline Study or Subqroup & Weight & $\begin{array}{c}\text { Odds Ratio } \\
\text { IV, Random, } 95 \% \mathrm{Cl}\end{array}$ & $\begin{array}{r}\text { Odds } \\
\text { IV, Rando }\end{array}$ & $\begin{array}{l}\text { s Ratio } \\
\text { om, } 95 \% \mathrm{Cl}\end{array}$ & \\
\hline \multicolumn{6}{|l|}{ 1.2.1 Adjusted Estimates } \\
\hline Adams 2007 & $19.1 \%$ & $0.41[0.21,0.79]$ & & & \\
\hline Scott 2013 & $32.7 \%$ & $0.54[0.44,0.67]$ & & & \\
\hline $\begin{array}{l}\text { Sjostrom } 2007 \text { and } 2012 \\
\text { Subtotal }(95 \% \mathrm{Cl})\end{array}$ & $\begin{array}{l}30.9 \% \\
82.7 \%\end{array}$ & $\begin{array}{l}0.71[0.54,0.94] \\
0.58[0.45,0.74]\end{array}$ & & & \\
\hline \multicolumn{6}{|c|}{$\begin{array}{l}\text { Heterogeneity: } \text { Tau }^{2}=0.02 ; \mathrm{Chi}^{2}=3.56, \mathrm{df}=2(P=0.17) ; \mathrm{I}^{2}=44 \% \\
\text { Test for overall effect: } Z=4.33(P<0.0001)\end{array}$} \\
\hline \multicolumn{6}{|c|}{ 1.2.2 Unadjusted Estimates } \\
\hline $\begin{array}{l}\text { Johnson } 2013 \\
\text { Subtotal }(95 \% \text { CI) }\end{array}$ & $\begin{array}{l}17.3 \% \\
17.3 \%\end{array}$ & $\begin{array}{l}0.17[0.08,0.35] \\
0.17[0.08,0.35]\end{array}$ & & & \\
\hline \multicolumn{6}{|c|}{$\begin{array}{l}\text { Heterogeneity: Not applicable } \\
\text { Test for overall effect: } Z=4.80(P<0.00001)\end{array}$} \\
\hline Total $(95 \% \mathrm{Cl})$ & $100.0 \%$ & $0.46[0.30,0.69]$ & & & \\
\hline \multicolumn{3}{|c|}{$\begin{array}{l}\text { Heterogeneity: } \text { Tau }^{2}=0.13 ; \mathrm{Chi}^{2}=14.18, \mathrm{df}=3(P=0.003) ; \mathrm{I}^{2}=79 \% \\
\text { Test for overall effect: } \mathrm{Z}=3.66(P=0.0003) \\
\text { Test for subgroup differences: } \mathrm{Chi}^{2}=9.95, \mathrm{df}=1(P=0.002), \mathrm{I}^{2}=89.9 \%\end{array}$} & $\begin{array}{ll}0.2 & 0.5 \\
\text { Favours sugery }\end{array}$ & $\begin{array}{c}1 \\
1 \\
\text { Favours n }\end{array}$ & $\begin{array}{l}5 \\
\text { rgery }\end{array}$ \\
\hline
\end{tabular}


Figure 5: Meta-analyses of adverse cardiovascular events risk after bariatric surgery as compared to no surgery

Odds Ratio Odds Ratio

Study or Subqroup

1.3.1 Adjusted Estimates

Adams 2007

Weight IV, Random, $95 \% \mathrm{CI}$

$10.9 \%$

$29.1 \%$

$0.43[0.14,1.31]$

$36.8 \%$

$0.59[0.37,0.95]$

$0.66[0.49,0.89]$

$\begin{array}{lcc}\text { Subtotal }(95 \% \mathrm{Cl}) & 76.9 \% & 0.63[0.49,0.80] \\ \text { Heterogeneity: } \mathrm{Tau}^{2}=0.00 ; \mathrm{Chi}^{2}=0.61, \mathrm{df}=2(\mathrm{P}=0.74) ; \mathrm{I}^{2}=0 \%\end{array}$

Test for overall effect: $Z=3.68(P=0.0002)$

1.3.2 Unadjusted Estimates

Johnson 2013

$23.1 \% \quad 0.26[0.14,0.48]$

Subtotal $(95 \% \mathrm{Cl})$

Heterogeneity: Not applicable

Test for overall effect: $Z=4.29(P<0.0001)$

Total $(95 \% \mathrm{Cl})$

$100.0 \%$

$0.49[0.32,0.75]$

Heterogeneity: $\mathrm{Tau}^{2}=0.10 ; \mathrm{Chi}^{2}=7.33, \mathrm{df}=3(\mathrm{P}=0.06) ; \mathrm{I}^{2}=59 \%$

Test for overall effect: $Z=3.29(P=0.0010)$

Test for subgroup differences: $\mathrm{Chi}^{2}=6.72$, df $=1(P=0.010), \mathrm{I}^{2}=85.1 \%$
IV, Random, $95 \% \mathrm{Cl}$

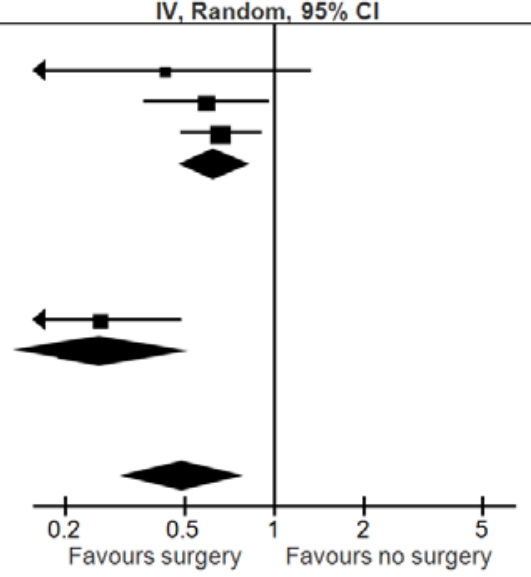


Supplement Data 1: Search Strategy

EMBASE, MEDLINE; ((bariatric surgery) AND ((acute coronary syndrome) OR (ischemic heart disease) OR (ischaemic heart disease) OR (coronary heart disease) OR (stroke) OR (cerebrovascular accident) OR (mortality) OR (cardiovascular disease))).ti,ab. 